\begin{tabular}{|l|l|l|}
\hline \multicolumn{2}{|c|}{ PublisherInfo } \\
\hline \hline PublisherName & $:$ & BioMed Central \\
\hline \hline PublisherLocation & $:$ & London \\
\hline \hline PublisherImprintName & $:$ & BioMed Central \\
\hline \hline
\end{tabular}

\title{
Diversity in axon guidance
}

\begin{tabular}{||l|l|l||}
\hline \multicolumn{2}{|c|}{ ArticleInfo } \\
\hline \hline ArticleID & $:$ & 3702 \\
\hline \hline ArticleDOI & $:$ & $10.1186 /$ gb-spotlight-20000616-01 \\
\hline \hline ArticleCitationID & $:$ & spotlight-20000616-01 \\
\hline \hline ArticleSequenceNumber & $:$ & 139 \\
\hline \hline ArticleCategory & $:$ & Research news \\
\hline \hline ArticleFirstPage & $:$ & 1 \\
\hline \hline ArticleLastPage & $:$ & 2 \\
\hline \hline & & RegistrationDate : 2000-06-16 \\
ArticleHistory & $:$ & OnlineDate \\
\hline \hline ArticleCopyright & $:$ & BioMed Central Ltd2000-06-16 \\
\hline \hline ArticleGrants & $:$ & \\
\hline \hline ArticleContext & $:$ & 130591111 \\
\hline \hline
\end{tabular}




\section{William Wells}

Email: wells@biotext.com

Thousands of alternatively spliced forms of an axon guidance receptor may contribute to the specificity of neuronal connections. The receptor, a Drosophila homolog of human Down syndrome cell adhesion molecule (DSCAM), was isolated thanks to its affinity with the axon guidance adaptor protein Dock, as reported in the June 9 Cell (Schmucker et al., Cell 2000, 101:671-684). Of DSCAM's ten extracellular immunoglobulin (Ig) domains, three of them have 12, 48, and 33 potential alternative sequences, respectively, in tandem arrangements. There are also two alternative transmembrane domains. Of 50 random DSCAM cDNAs, 49 had unique combinations of exons, suggesting that close to the theoretical maximum of 38,016 isoforms may be made by collections of neurons. Multiple isoforms of the human protein have not yet been detected, but an excess of the protein may contribute to neurological defects seen in Down syndrome.

\section{References}

1. DSCAM: a novel member of the immunoglobulin superfamily maps in a Down syndrome region and is involved in the development of the nervous system.

2. Drosophila photoreceptor axon guidance and targeting requires the dreadlocks $\mathrm{SH}$ /SH3 adapter protein.

3. Cell Magazine, [http://www.cell.com/]

This PDF file was created after publication. 